\title{
PENGARUH VARIASI KARBURATOR DAN BAHAN BAKAR TERHADAP KINERJA MESIN DAN EMISI GAS BUANG PADA SEPEDA MOTOR SUZUKI THUNDER 125 CC
}

\author{
Dwi Ari Raharjo \\ Teknik Mesin , Fakultas Teknik \\ Universitas Maarif Hasyim Latif, Sidoarjo, Indonesia \\ e-mail : dwi-ari-raharjo@student.umaha.ac.id
}

\begin{abstract}
ABSTRAK
Komponen penting setiap kendaraan bermotor yaitu karburator. Karburator berfungsi mencampur bahan bakar dan udara yang seimbang di mesin kendaraan bermotor. Perbandingan bahan bakar dan udara yang seimbang di ruang bakar membutuhkan pembakaran yang sempurna, pada umumnya perbandingan udara dan bahan bakar pada mesin adalah $1: 15$ yaitu 1 gram bensin dan 15 gram udara.Karburator Suzuki thunder 125 ini menggunakan sistem vakum. Suzuki thunder $125 \mathrm{cc}$ sebagai bahan penelitian tugas akhir dengan cara memvariasikan antara karburator konvensional dengan karburator vakum. Tujuan dari penelitian adalah Mengetahui pengaruh variasi karburator dan bahan bakar terhadap torsi yang dihasilkan pada sepeda motor suzuki thunder $125 \mathrm{cc}$. Mengetahui pengaruh variasi karburator dan bahan bakar terhadap daya, torsi, konsumsi bahan bakar, dan emisi gas buang yang dihasilkan sepeda motor suzuki thunder $125 \mathrm{cc}$. Pengaruh variasi karburator dan bahan bakar terhadap torsi dan daya yang dihasilkan sepeda motor suzuki thunder $125 \mathrm{cc}$ yang paling bagus yaitu dengan menggunakan karburator konvensional RX-King merk lippo dengan bahan bakar pertamax dengan hasil 7.65 N.m dan hasil 10.5 HP. Pengaruh variasi karburator dan bahan bakar terhadap penggunaan bahan bakar yang dihasilkan sepeda motor suzuki thunder 125cc yang paling bagus menggunakan karburator vakum Satria FU dengan bahan bakar pertamax dengan hasil rata-rata 131.4 detik per $10 \mathrm{ml}$ dan terhadap emisi gas buang yang dihasilkan sepeda motor suzuki thunder $125 \mathrm{cc}$ yang paling bagus menggunakan karburator vakum Satria FU dengan bahan bakar pertamax dengan hasil senyawa $\mathrm{CO}=0.03 \%, \mathrm{CO} 2=2.8 \%, \mathrm{HC}=120 \mathrm{ppm}$ dan $02=16.50 \%$.
\end{abstract}

Kata kunci: bahan bakar, daya, emisi gas buang, karburator vakum, torsi, variasi

\section{PENDAHULUAN}

Perkembangan ilmu pengetahuan dan teknologi merupakan sarana penunjang pelaksanaan kemajuan suatu negara, salah satunya adalah dibidang industri dan permesinan. Kemajuan bidang teknologi mesin sekarang ini, khususnya otomotif berkembang dengan pesat. Pertama kali ditemukan oleh nikolaus august otto pada tahun 1876 orang kebangsaan jerman, menemukan sebuah mesin dengan sistem pembakaran dalam, dari tahun ke tahun mesin tersebut dikembangkan dan mengalami kemajuan yang pesat hingga sekarang, mesin sistem pembakaran dalam menjadi pilihan untuk sarana dan prasarana alat transportasi yang diminati masyarakat, misalnya sepeda motor. Berkembangnya ilmu pengetahuan dan teknologi, berbagai alat diciptakan untuk kebutuhan manusia. Salah satunya adalah bidang otomotif, dimana dalam penggunaanya diperlukan pengetahuan tentang mesin sehingga dapat bekerja secara efisien dan efektif.

Komponen penting setiap kendaraan bermotor yaitu karburator. Karburator berfungsi mencampur bahan bakar dan udara yang seimbang di mesin kendaraan bermotor. Perbandingan bahan bakar dan udara yang seimbang di ruang bakar membutuhkan pembakaran yang sempurna, pada umumnya perbandingan udara dan bahan bakar pada mesin adalah $1: 15$ yaitu 1 gram bensin dan 15 gram udara. Teknologi motor bakar menjadi teknolgi yang sangat membantu kehidupan manusia. Seiring berkembangnya sistem pembakaran yang semakin pesat membuat teknologi yang lama akan tertinggal dan diperlukan pembaruan.

Dari latar belakang ini saya memilih suzuki thunder $125 \mathrm{cc}$ sebagai bahan penelitian tugas akhir dengan cara memvariasikan antara karburator konvensional dengan karburator vakum. Alasan memilih sepeda motor ini karena sepeda motor ini di sebagian daerah hampir tidak diminati oleh masyarakat. Menurut saya faktor penyebab kurangnya di minati oleh masyarakat ini di karenakan sulitnya mencari sparepart motor ini salah satunya di karburatornya dan mesin yang didapati kurang responsif. Karena sepeda motor ini hampir tidak diminati oleh masyarakat, saya lebih tertantang untuk membuktikan bahwa sepeda motor ini pantas diminati ketimbang sepeda motor sport $125 \mathrm{cc}$ merk lainnya. Karburator suzuki thunder 125 ini menggunakan sistem vakum, apabila vakumnya sobek karburator tidak bisa berfungsi. Dibandingkan dengan konvensional, karburator konvensional lebih praktis cara kerjanya dengan menggunakan kabel gas langsung 
ke skep. Pada penelitian saya ini akan membuahkan jawaban keluh kesah dari pemilik motor thunder 125cc.

\section{METODE PENELITIAN}

Adapun prosedur penelitian "Pengaruh variasi karburator dan bahan bakar terhadap kinerja mesin dan emisi gas buang pada sepeda motor suzuki thunder $125 \mathrm{cc}$ " yang dijelaskan dalam diagram alir berikut ini :

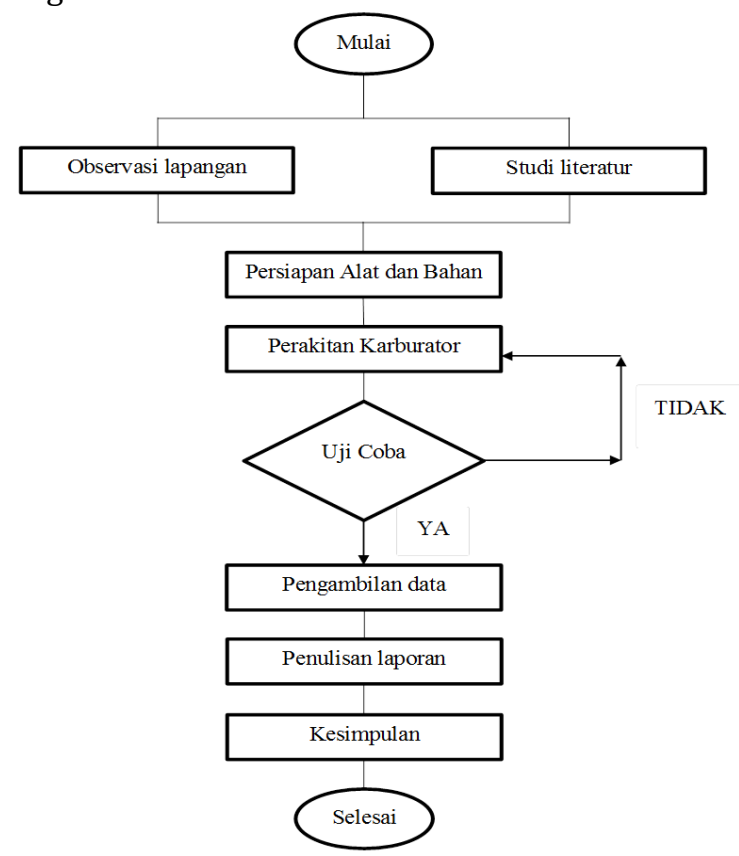

Gambar 1. Diagram alir perencanaan pengerjaan

Alat dan Bahan yang digunakan

A. Alat :

1. Obeng $(+)$ dan Obeng $(-)$

2. Kunci pas dan Kunci ring ukuran $10 \mathrm{~mm}$

3. Alat uji dynotest

4. Alat uji gas analyzer

5. Gelas bahan bakar dengan ukuran

6. Tachometer

7. Hp android

8. Flashdisk

B. Bahan :

1. Karburator vakum dari sepeda motor suzuki Satria FU

2. Karburator konvensional RX- King merk lippo diameter venturi $26 \mathrm{~mm}$

3. Bahan bakar pertalite

4. Bahan bakar pertamax

\section{HASIL DAN PEMBAHASAN}

\section{Definisi Dynotest}

Dynotest digunakan untuk mengukur kinerja maksimal dari torsi dan daya pada sepeda motor.. Torsi merupakan kemampuan mesin untuk menggerakkan sebuah kendaraan dari kondisi diam sampai berjalan, torsi ini berkaitan dengan akselerasi kendaraan. Sedangkan daya diartikan, seberapa cepat kendaraan mencapai sebuah kecepatan tertentu.

Perangkat mesin yang mendukung kinerja dyno test diantaranya roller, blower, sistem pengaman, dan pengunci motor supaya tidak goyang saat motor digas penuh di atas mesin dynotest. Hasil dari pengujian tersebut selanjutnya ditampilkan pada layar komputer.

\section{Persiapan alat dan bahan pendukung untuk uji} dynotest

1. Obeng (+) dan obeng (-)

2. Sepeda motor Suzuki thunder $125 \mathrm{cc}$.

3. Karburator konvensional RX-King merk lippo $26 \mathrm{~mm}$ dan karburator vakum milik suzuki Satria FU.

4. Bahan bakar pertamax dan pertalite.

5. Hp android dan flashdisk.

\section{Persiapan untuk pengujian dynotest}

1. Naikkan motor di mesin uji dynotest.

2. Pasang sistem pengaman berupa sabuk untuk roda depan sepeda motor.

3. Pasang kabel dari mesin uji dynotest ke kabel busi sepeda motor.

4. Pasang sabuk pengaman sepeda motor pada roda depan body sepeda motor supaya sepeda motor tidak goyang ketika proses pengujian.

5. Pasang karburatoryang akan di uji pada mesin dynotest yaitu karburator konvensional RX-King merk lippo 26mm / karburator vakum milik Suzuki Satria FU.

6. Masukkan bahan bakaryang akan di uji yaitu pertamax / pertalite pada tangki bahan bakar.

7. Lakukan pengujian.

8. Ulangi tahap - tahap sesuai yang di inginkan.
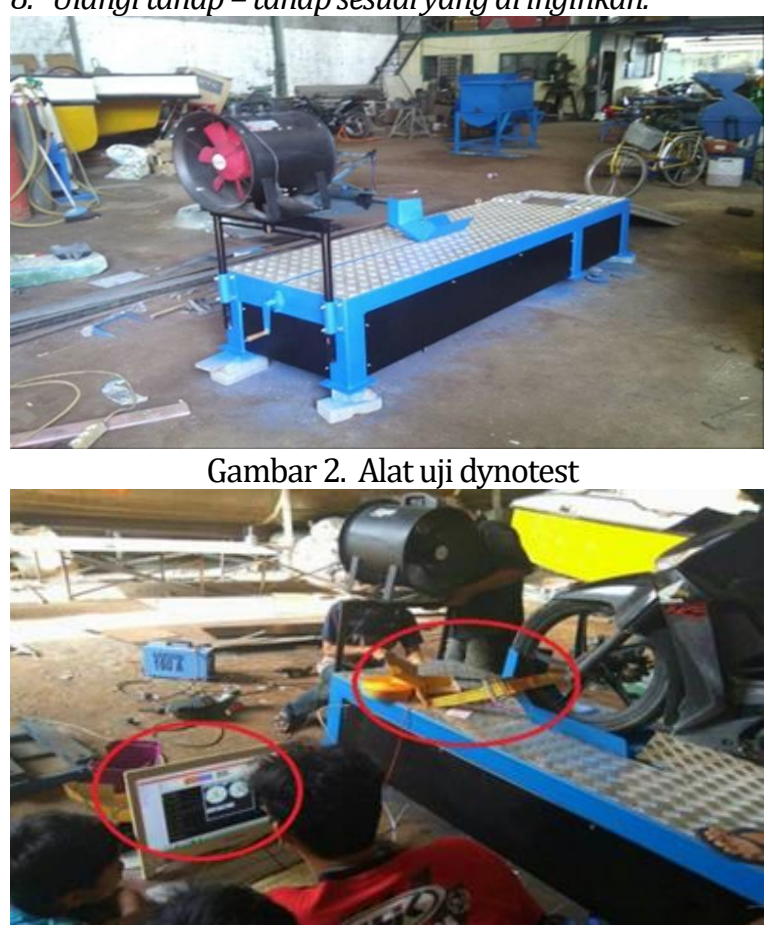

Gambar 3. Sabuk pengikat dan komputer pendukung 
Tabel 4.1 Uji dynotest variasi karburator dan bahan

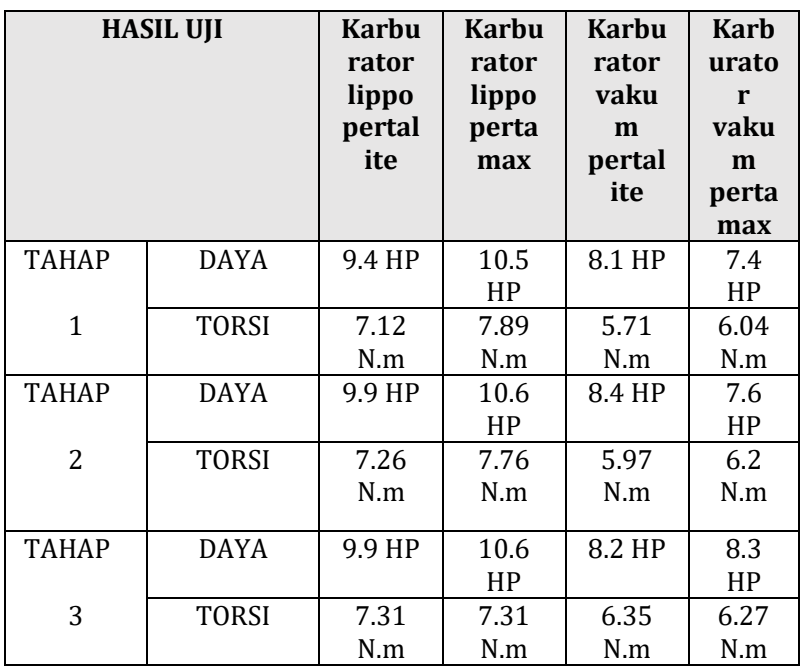

bakar

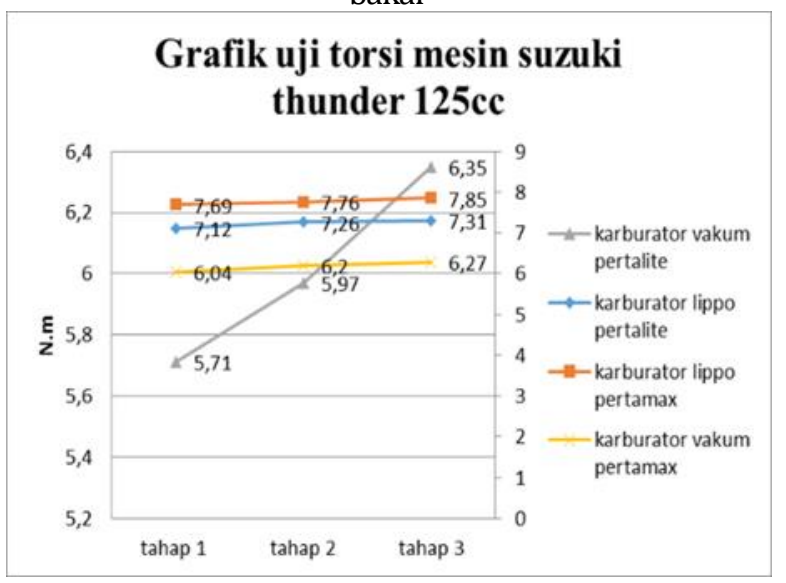

Gambar 4. Grafik hasil uji torsi Suzuki thunder 125 cc

\section{Grafik uji daya mesin suzuki thunder 125}

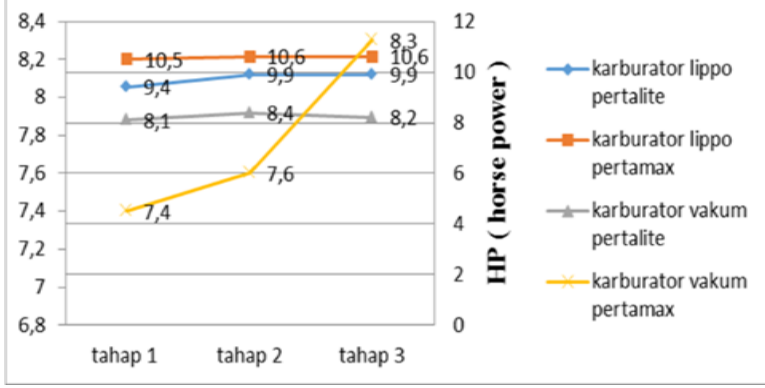

Gambar 5. Grafik hasil uji daya Suzuki thunder 125cc

\section{Keterangan :}

\section{Tahap 1}

A. Hasil torsi dari karburator konvensional RX-King merk lippo bahan bakar pertalite adalah Tahap $1=7.12$ N.m, Tahap $2=7.26$ N.m , Tahap $3=7.31$ N.m.

B. Hasil daya dari karburator konvensional RX-King merk lippo bahan bakar pertalite adalah Tahap $1=9.4 \mathrm{HP}$, Tahap $2=9.9 \mathrm{HP}$, Tahap $3=9.9 \mathrm{HP}$

Dapat disimpulkanl rata-rata 7.23 N.m untuk torsinya dan 9.7 HP untuk.
Tahap 2

A. Hasil torsi dari karburator konvensional RX-King merk lippo bahan bakar pertamax adalah Tahap $1=$ 7.89 N.m, Tahap $2=7.76$ N.m, Tahap $3=7.31$ N.m B. Hasil daya dari karburator konvensional RX-king merk lippo bahan bakar pertamax adalah Tahap $1=$ 10.5 HP, Tahap $2=10.6 \mathrm{HP}$, Tahap $3=10.6 \mathrm{HP}$

Dapat disimpulkanl rata-rata 7.65 N.m untuk torsinya dan 10.5 HP untuk dayanya.

\section{Tahap 3}

A. Hasil torsi dari karburator vakum Satria FU bahan

bakar pertalite adalah Tahap $1=5.71 \mathrm{~N} . \mathrm{m}$, Tahap $2=$ 5.97 N.m Tahap $3=6.35$ N.m

B. Hasil daya dari karburator vakum Satria FU bahan bakar pertalite adalah Tahap $1=8.1 \mathrm{HP}$, Tahap $2=8.4$ HP , Tahap $3=8.2 \mathrm{HP}$

Dapat disimpulkanl rata-rata 6.01 N.m untuk torsinya dan 8.2 HP untuk dayanya.

\section{Tahap 4}

A. Hasil torsi dari karburator vakum Satria FU bahan bakar pertamax adalah Tahap $1=6.04$ N.m, Tahap $2=$ $6.2 \mathrm{~N} . \mathrm{m}$, Tahap $3=6.27 \mathrm{~N} . \mathrm{m}$

B. Hasil daya dari karburator vakum Satria FU bahan bakar pertamax adalah Tahap $1=7.4 \mathrm{HP}$, Tahap $2=$ 7.6 HP , Tahap $3=8.3 \mathrm{HP}$

Dapat disimpulkanl rata-rata 6.17 N.m untuk torsinya dan 7.7 HP untuk dayanya.

\section{Uji Konsumsi Bahan Bakar}

1. Pengertian uji konsumsi bahan bakar Uji Konsumsi bahan bakar adalah dimana peneliti mengukur cepat atau lambatnya bahan bakar yang berkurang pada suatu kendaraan bermotor dalam hitungan detik dengan rpm yang ditentukan sesuai keinginan peneliti.

2. Persiapan Percobaan

1. Pasang karburator konvensional lippo dan vakum secara bergantian.

2. Pemeriksaan minyak pelumas mesin.

3. Pemeriksaan sistim bahan bakar.

4. Tabung gelas ukur untuk mengukur konsumsi bahan bakar ukuran $100 \mathrm{ml}$.

5. Stopwatch untuk mengukur waktu untuk menghabiskan bahan bakar per $10 \mathrm{ml}$.

6. Tachometer untuk mengukur putaran mesin.

3. Pengambilan Data

1. Cek kondisi karburator apakah sudah normal dan siap di uji.

2. Hidupkan mesin dan lakukan pemanasan.

3. Naikkan putaran mesin sampai $2000-2200$ rpm, 3000 - 3200 rpm dan 4000 - 4200 rpm secara bergantian sesuai kondisi karburator

4. Siapkan stopwatch, lalu catat konsumsi bahan bakar per $10 \mathrm{ml}$

5. Lakukan langkah 3 dan sebanyak 3 kali

6. Setelah selesai turunkan putaran mesin lalu matikan. 
Ganti bahan bakar dan karburator sesuai yang diinginkan

Tabel 4.2 Data percobaan konsumsi bahan bakar

\begin{tabular}{|c|c|c|c|}
\hline $\begin{array}{l}\text { Putaran } \\
\text { (rpm ) }\end{array}$ & $\begin{array}{l}\text { Jenis } \\
\text { karburator } \\
\text { dan bahan } \\
\text { bakar }\end{array}$ & $\begin{array}{l}\text { Waktu per } \\
\text { 10ml } \\
\text { ( detik ) } \\
\text { bahan } \\
\text { bakar }\end{array}$ & $\begin{array}{l}\text { Keterangan } \\
\text { putaran } \\
\text { mesin } \\
\text { sebenarnya }\end{array}$ \\
\hline \multirow{4}{*}{$\begin{array}{l}2000 \\
\text { sampai } \\
2200\end{array}$} & $\begin{array}{l}\text { Karburator } \\
\text { lippo pertalite }\end{array}$ & 98.06 & 2140 \\
\hline & $\begin{array}{l}\text { Karburator } \\
\text { lippo pertamax }\end{array}$ & 101.6 & 2140 \\
\hline & $\begin{array}{l}\text { Karburator } \\
\text { vakum } \\
\text { pertalite }\end{array}$ & 120.6 & 2140 \\
\hline & $\begin{array}{l}\text { Karburator } \\
\text { vakum } \\
\text { pertamax }\end{array}$ & 150.8 & 2140 \\
\hline \multirow{4}{*}{$\begin{array}{l}3000 \\
\text { sampai } \\
3200\end{array}$} & $\begin{array}{l}\text { Karburator } \\
\text { lippo pertalite }\end{array}$ & 86.1 & 3100 \\
\hline & $\begin{array}{l}\text { Karburator } \\
\text { lippo pertamax }\end{array}$ & 99.2 & 3100 \\
\hline & $\begin{array}{l}\text { Karburator } \\
\text { vakum } \\
\text { pertalite }\end{array}$ & 111.8 & 3100 \\
\hline & $\begin{array}{l}\text { Karburator } \\
\text { vakum } \\
\text { pertamax }\end{array}$ & 131.6 & 3100 \\
\hline \multirow{5}{*}{$\begin{array}{l}4000 \\
\text { sampai } \\
4200\end{array}$} & $\begin{array}{l}\text { Karburator } \\
\text { lippo pertalite }\end{array}$ & 64.2 & 4100 \\
\hline & $\begin{array}{l}\text { Karburator } \\
\text { lippo pertamax }\end{array}$ & 68.8 & 4100 \\
\hline & $\begin{array}{l}\text { Karburator } \\
\text { vakum } \\
\text { pertalite }\end{array}$ & 85.9 & 4100 \\
\hline & $\begin{array}{l}\text { Karburator } \\
\text { vakum } \\
\text { pertamax }\end{array}$ & 111.8 & 4100 \\
\hline & $\begin{array}{l}\text { Karburator } \\
\text { lippo pertalite }\end{array}$ & 98.06 & 2140 \\
\hline
\end{tabular}

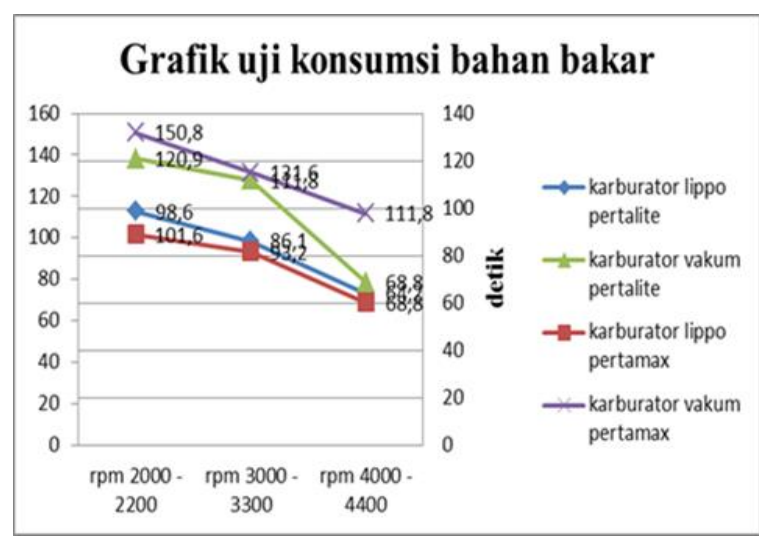

Gambar 6. Grafik hasil uji konsumsi bahan bakar

Keterangan :

1. Hasil dari uji konsumsi bahan bakar karburator konvensional lippo bahan bakar pertalite adalah Rpm 2000 - $2200=98.6$ detik per $10 \mathrm{ml}, \mathrm{Rpm} 3000$ $-3200=86.1$ detik per 10 ml , Rpm $4000-4200=$ 64.2 detik per $10 \mathrm{ml}$.

2. Hasil dari uji konsumsi bahan bakar karburator konvensional lippo bahan bakar pertamax adalah
Rpm $2000-2200=101.6$ detik per 10ml , Rpm $3000-3200=99.2$ detik per 10 ml , Rpm $4000-$ $4200=68.8$ detik per $10 \mathrm{ml}$.

3. Hasil dari uji konsumsi bahan bakar karburator vakum satria fu bahan bakar pertalite adalah Rpm $2000-2200=120.6$ detik per 10ml , Rpm 3000 $3200=111.8$ detik per $10 \mathrm{ml}, \mathrm{Rpm} 4000-4200=$ 85.9 detik per $10 \mathrm{ml}$.

4. Hasil dari uji konsumsi bahan bakar karburator vakum satria fu bahan bakar pertamax adalah Rpm $2000-2200=150.8$ detik per $10 \mathrm{ml}, \mathrm{Rpm} 3000-$ $3200=131.6$ detik per $10 \mathrm{ml}, \mathrm{Rpm} 4000-4200=$ 111.8 detik per $10 \mathrm{ml}$.

\section{Uji emisi gas buang}

Emisi gas buang adalah sisa hasil pembakaran bahan bakar di dalam mesin pembakaraan dalam. Sisa hasil pembakaran berupa air ( $\mathrm{H} 20$, gass $\mathrm{CO}$ atau disebut karbon monoksida yang beracun, $\mathrm{CO} 2$ atau disebut karbon dioksida yang merupakan gas rumah kaca, NO senyawa nitrogen oksida, HC berupa senyawa Hidrat arang sebagai alat ketidak sempurnaan proses pembakaran serta partikel lepas.

Dampak negatif

Kerugian yang ditimbulkan dari emisi gas buang adalah:

1. Pemicu hipertensi

2. Menyebabkan iritasi mata

3. Menurunkan kecerdasan otak

4. Mengganggu perkembangan mental anak

5. Menyebabkan Tenggorokan gatal dan batuk - batuk

6. Mengurangi fungsi reproduksi laki- laki

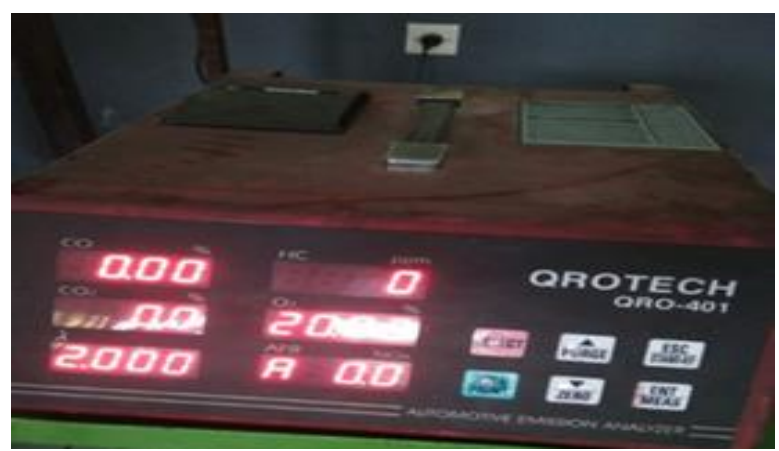

Gambar 7. Alat uji emisi gas buang (gas analyzer)

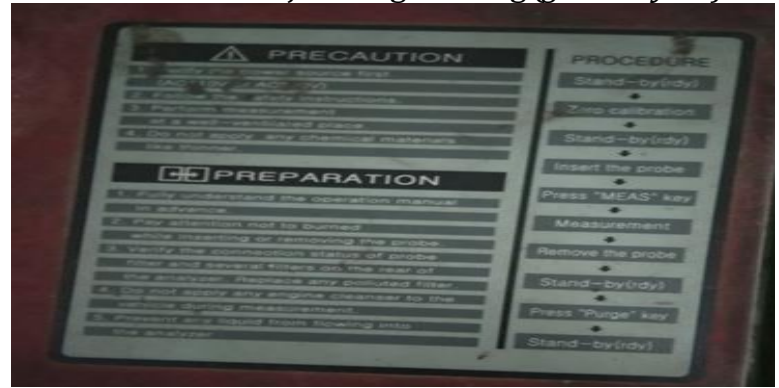

Gambar 8. Petunjuk penggunaan gas analyzer (alat uji emisi gas buang) 


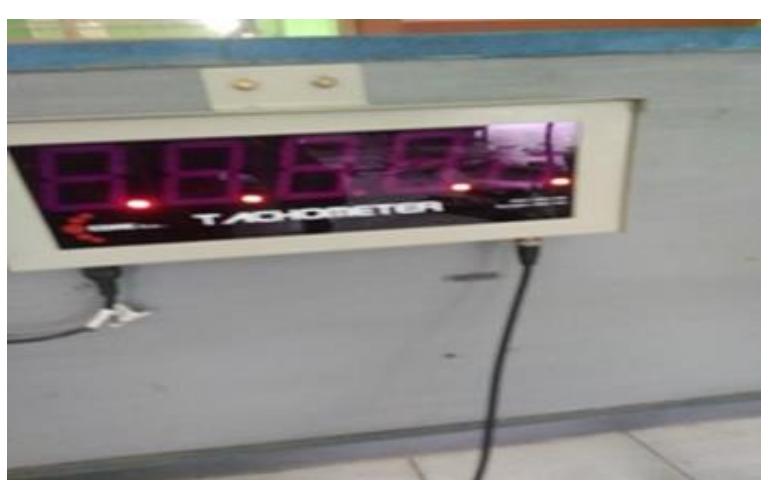

Gambar 8. Tachometer digital

\section{Persiapan percobaan}

1. Tentukan karburator dan bahan bakar yang akan diujikan

2. Nyalakan mesin sepeda motor

3. Tancapkan kabel tacho meter pada kabel busi

4. Persiapkan alat gas analyzer dengan mengikuti petunjuk pada gambar diatas

5. Tancapkan sensor penghubung antara knalpot dengan alat gas analyzer.

6. Tunggu hasil dari alat uji gas analyzer

7. Pengambilan data berupa foto pada alat gas analyzer

8. Ulangi langkah seperti awal karena pengujian menggunakan 2 karburator dan 2 bahan bakar yang berbeda.

Tabel 3. Uji emisi gas buang

\begin{tabular}{|c|c|c|c|c|}
\hline $\begin{array}{c}\text { Jenis } \\
\text { Karburator } \\
\text { dan bahan } \\
\text { bakar }\end{array}$ & $\begin{array}{c}\text { CO } \\
\text { (\%) }\end{array}$ & $\begin{array}{c}\text { CO2 } \\
\text { (\%) }\end{array}$ & $\begin{array}{c}\text { HC } \\
\text { (ppm) }\end{array}$ & $\begin{array}{c}\mathbf{0 2} \\
\mathbf{( \% )}\end{array}$ \\
\hline $\begin{array}{c}\text { Karburator } \\
\text { lippo bahan } \\
\text { bakar } \\
\text { pertalite }\end{array}$ & 4.33 & 3.5 & 394 & 11.39 \\
\hline $\begin{array}{c}\text { Karburator } \\
\text { lippo bahan } \\
\text { bakar } \\
\text { pertamax }\end{array}$ & 3.40 & 2.8 & 331 & 13.5 \\
\hline $\begin{array}{c}\text { Karburator } \\
\text { vakum } \\
\text { bahan } \\
\text { bakar } \\
\text { pertalite }\end{array}$ & 0.64 & 2.9 & 204 & 16.14 \\
\hline $\begin{array}{c}\text { Karburator } \\
\text { vakum } \\
\text { bahan } \\
\text { bakar } \\
\text { pertamax }\end{array}$ & 0.03 & 2.8 & 120 & 16.50 \\
\hline
\end{tabular}

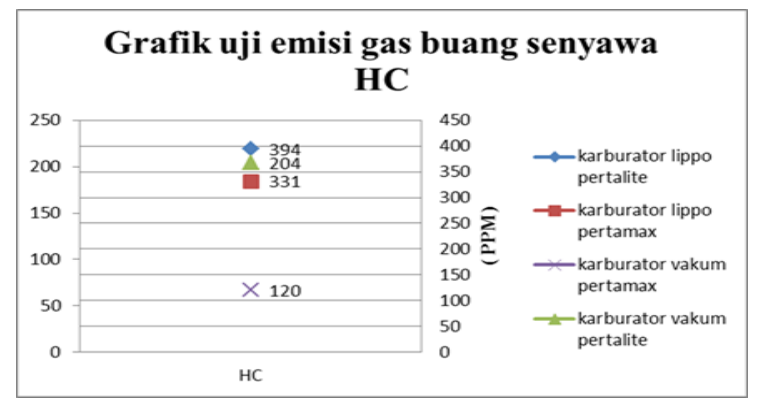

Gambar 11. Grafik hasil uji emisi gas buang senyawa HC

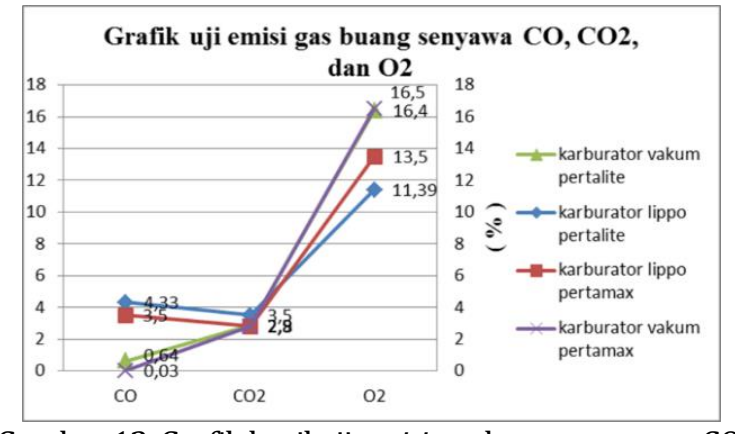

Gambar 12. Grafik hasil uji emisi gas buang senyawa CO, $\mathrm{CO} 2$, dan 02

\section{PENUTUP}

\section{Kesimpulan}

1. Dapat disimpulkan pengaruh variasi karburator dan bahan bakar terhadap torsi yang dihasilkan pada sepeda motor suzuki thunder $125 \mathrm{cc}$ yang paling bagus yaitu dengan menggunakan karburator konvensional rx-king merk lippo dengan bahan bakar pertamax dengan hasil $7.65 \mathrm{n} . \mathrm{m}$

2. Dapat disimpulkan pengaruh variasi karburator dan bahan bakar terhadap daya yang dihasilkan pada sepeda motor suzuki thunder $125 \mathrm{cc}$ yang paling bagus yaitu dengan menggunakan karburator konvensional rx-king merk lippo dengan bahan bakar pertamax dengan hasil $10.5 \mathrm{hp}$

3. Dapat disimpulkan pengaruh variasi karburator dan bahan bakar terhadap penggunaan bahan bakar yang dihasilkan pada sepeda motor suzuki thunder $125 \mathrm{cc}$ yang paling bagus menggunakan karburator vakum satria fu dengan bahan bakar pertamax dengan hasil rata-rata 131.4 detik per $10 \mathrm{ml}$.

4. Dapat disimpulkan pengaruh variasi karburator dan bahan bakar terhadap emisi gas buang yang dihasilkan pada sepeda motor suzuki thunder $125 \mathrm{cc}$ yang paling bagus menggunakan karburator vakum satria fu dengan bahan bakar pertamax dengan hasil senyawa co $=0.03 \%, \mathrm{co} 2=2.8 \%, \mathrm{hc}=120 \mathrm{ppm}$ dan o2 $=16.50 \%$.

\section{Saran}

1. Pada hasil perbandingan karburator dan variasi bahan bakar peneliti menyarankan pada pengguna sepeda motor suzuki thunder $125 \mathrm{cc}$ untuk menggunakan karburator konvensional rx-king merk lippo dengan bahan bakar pertamax karena hasil dari penelitian menunjukkan hasil torsi yang paling tinggi.

2. Pada hasil perbandingan karburator dan variasi bahan bakar peneliti menyarankan pada pengguna sepeda motor suzuki thunder $125 \mathrm{cc}$ untuk menggunakan karburator konvensional rx-king merk lippo dengan bahan bakar pertamax karena hasil dari penelitian menunjukkan hasil power yang paling tinggi.

3. Pada hasil perbandingan karburator dan variasi bahan bakar peneliti menyarankan pada pengguna sepeda motor suzuki thunder $125 \mathrm{cc}$ untuk 
menggunakan karburator vakum satria fu dengan bahan bakar pertamax untuk pengguna sepeda motor thunder yang menginginkan ke iritan bahan bakar karena hasil dari penelitian menunjukkan hasil dari karburator dan bahan bakar pertamax tersebut yang paling lama waktunya

4. Pada hasil perbandingan variasi karburator dan bahan bakar peneliti menyarankan pada pengguna sepeda motor suzuki thunder $125 \mathrm{cc}$ untuk menggunakan karburator vakum satria fu dengan bahan bakar pertamax karena dari hasil penelitian emisi gas buang karburator dan bahan tersebut menghasilkan gas buang senyawa co, co2, hc yang paling sedikit dan senyawa o2 yang paling tinggi dari hasil tersebut menggunakan karburator dan bahan bakar ini menghasilkan gas buang yang ramah lingkungan, aman dan sehat untuk udara sekitar.

\section{DAFTAR PUSTAKA}

Afifah, Y. N. (2016). ALIRAN TAK TUNAK FLUIDA NANO MAGNETOHIDRODINAMIK ( MHD ) YANG MELEWATI BOLA.

Afifah, Y. N. (2019). Analysis of Unsteady Magneto Hydro Dynamic (MHD) Nano Fluid Flow Past A Sliced Sphere. IOP Conference Series: Materials Science and Engineering, 494(1). https://doi.org/10.1088/1757899X/494/1/012033

Afifah, Y. N., \& Putra, B. C. (2018). Model Matematika Aliran Tak Tunak Pada Nano Fluid Melewati Bola Teriris Dengan Pengaruh Medan Magnet. Teknika: Engineering and Sains Journal, 2(2), 119-124.

Akhir, P., Akhir, P., Oleh, D., Nim, N., \& Suyanto, E. K. O. (2014). Analisa Pengaruh Perubahan Main Jet dan Pilot Jet Terhadap Peforma Motor Honda Beat.

Farisi, A. S., \& Sakti, A. M. (2016). Pengaruh Variasi. Jtm, 04(02), 1-6.

Gunawan, E. et al. (2019) 'Analysis of the Effect of Current Flow Variations in GTAW on SS 400 Plate Material Connected with SUS 304 Stainless Steel Plate Against Tensile Strength and Hardness with ER308L Electrodes', Journal of Physics: Conference Series, 1175(1). doi: 10.1088/1742-6596/1175/1/012277.

Herdyana fajar km. (n.d.). cara setting ukuran spuyer motor. Retrieved from http://accentirex.blogspot.com/2012/03/car a-setting-ukuran-spuyer-motor.html

Herlambang, A. (n.d.). komponen karburator. Retrieved from http://otomediashare.blogspot.com/2016/0 2/komponen-karburator-sepeda-motordan.html
Hidayat, R. (n.d.). jenis karburator. Retrieved from https://www.kitapunya.net/2013/12/jenisjenis-karburator.html

Motor, P., \& Dalam, P. (n.d.). 1 Teori Dasar. (Gambar 5), 1-19.

Nugroho, A., \& Khafid, N. (n.d.). DAN VARIASI PUTARAN MESIN TERHADAP KONSUMSI BAHAN BAKAR PADA SEPEDA MOTOR HONDA SUPRA X 125.

Panaekan. (n.d.). ukuran pilot jet dan main jet standar. Retrieved from https://repository.polibatam.ac.id/uploads/2 15207-20170822050808.pdfomponenkarburator-sepeda-motor-dan.html

Putra, B. C., \& Afifah, Y. N. (2018). Gaussian Mixture Model Untuk Penghitungan Tingkat. Teknika: Engineering and Sains Journal, 2, 53-58.

Qomarudin, M. H., Metyana, A. C. and Afifah, Y. N. (2020) 'Analisis Kestabilan dan Travelling Wave pada Model Penyebaran Virus Ebola', Briliant: Jurnal Riset dan Konseptual, 5(2), p. 369. doi: 10.28926/briliant.v5i2.441.

Rahmawati, P. (2015). Pengaruh Variasi Produk ... 89-98.

Satria, M. (n.d.). cara kerja karburator. Retrieved from http://motorsatria.com/cara-kerjakarburator

Yunita Nur Afifah, MNH Qomarudin, \& Imamatul Ummah. (2020). Optimal Control Model Pemanenan Prey-Predator di Area Konservasi Ikan. Buana Matematika: Jurnal Ilmiah Matematika Dan Pendidikan Matematika, 10(1), 1-16. https://doi.org/10.36456/buanamatematika. v10i1.2410 